OPEN ACCESS

Approved by:

Frontiers Editorial Office Frontiers Media SA, Switzerland

${ }^{*}$ Correspondence:

Peter Deines

pdeines@zoologie.uni-kiel.de

†Present address

Peter Deines,

RD3 Marine Symbioses, GEOMAR

Helmholtz Centre for Ocean Research

Kiel, Kiel, Germany

Specialty section:

This article was submitted to

Microbial Symbioses,

a section of the journal

Frontiers in Microbiology

Received: 25 November 2020 Accepted: 04 December 2020

Published: 12 January 2021

Citation:

Deines $P$, Hammerschmidt $K$ and Bosch TCG (2021) Corrigendum: Exploring the Niche Concept in a

Simple Metaorganism.

Front. Microbiol. 11:633429.

doi: $10.3389 /$ fmicb.2020.633429

\section{Corrigendum: Exploring the Niche Concept in a Simple Metaorganism}

\author{
Peter Deines ${ }^{1 * \dagger}$, Katrin Hammerschmidt ${ }^{2}$ and Thomas C. G. Bosch ${ }^{1}$ \\ ${ }^{1}$ Zoological Institute, Christian Albrechts University Kiel, Kiel, Germany, ${ }^{2}$ Institute of General Microbiology, Christian Albrechts \\ University Kiel, Kiel, Germany
}

Keywords: fundamental niche, realized niche, microbiome, species abundance, microbial traits, Hydra

\section{A Corrigendum on}

Exploring the Niche Concept in a Simple Metaorganism

by Deines, P., Hammerschmidt, K., and Bosch, T. C. G. (2020). Front. Microbiol. 11:1942. doi: $10.3389 /$ fmicb.2020.01942

In the published article, there was an error regarding the affiliations for Peter Deines. As well as having affiliation 1, he should also have RD3 Marine Symbioses, GEOMAR Helmholtz Centre for Ocean Research Kiel, Kiel, Germany as a present address.

The authors apologize for this error and state that this does not change the scientific conclusions of the article in any way. The original article has been updated.

Copyright $\odot 2021$ Deines, Hammerschmidt and Bosch. This is an open-access article distributed under the terms of the Creative Commons Attribution License (CC BY). The use, distribution or reproduction in other forums is permitted, provided the original author(s) and the copyright owner(s) are credited and that the original publication in this journal is cited, in accordance with accepted academic practice. No use, distribution or reproduction is permitted which does not comply with these terms. 